\title{
Cholesterol lowering with simvastatin reduced stroke in patients with, or at risk of, vascular disease
}

Collins R, Armitage J, Parish S, et al. Effects of cholesterol-lowering with simvastatin on stroke and other major vascular events in 20 536 people with cerebrovascular disease or other high-risk conditions. Lancet 2004;363:757-67.

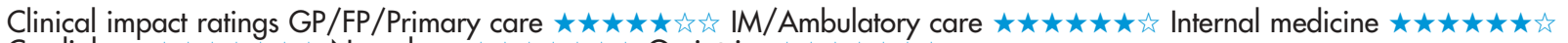

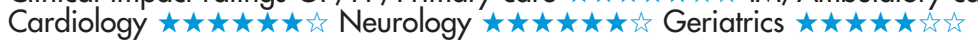

Does cholesterol lowering with simvastatin reduce the incidence of stroke in patients with, or at high risk of, vascular disease?

\section{METHODS}

\begin{tabular}{|c|c|}
\hline & Design: randomised controlled trial (Heart Protection Study). \\
\hline & Allocation: $\{$ concealed $*\}$ t. \\
\hline & $\begin{array}{l}\text { Blinding: blinded \{patients, clinicians, and data monitoring } \\
\text { committee\}t.* }\end{array}$ \\
\hline & Follow up period: 5 years. \\
\hline & Setting: $\{69$ hospitals in the UK\}t. \\
\hline & $\begin{array}{l}\text { Patients: } 20536 \text { patients (mean age } 64 \text { y, } 75 \% \text { men) who had } \\
\text { non-fasting total cholesterol concentrations } \geqslant 3.5 \mathrm{mmol} / / \mathrm{l} \text { ( } 135 \\
\mathrm{mg} / \mathrm{dl} \text { ) and a medical history of cerebrovascular disease, } \\
\text { coronary disease, other occlusive arterial disease, or diabetes, or } \\
\text { were men } \geqslant 65 \text { years of age treated for hypertension. Exclusion } \\
\text { criteria: clear indication or contraindication for statin therapy; } \\
\text { stroke, myocardial infarction, or admission for angina in the } \\
\text { previous } 6 \text { months; chronic liver disease; severe renal disease; } \\
\text { inflammatory muscle disease; concurrent treatment with } \\
\text { cyclosporin, fibrates, or high dose niacin; child bearing potential; } \\
\text { severe heart failure; or life threatening conditions. }\end{array}$ \\
\hline & $\begin{array}{l}\text { Intervention: simvastatin, } 40 \mathrm{mg} \text { daily }(\mathrm{n}=10269) \text {, or matching } \\
\text { placebo }(n=10267 \text { ) for } 5 \text { years. }\end{array}$ \\
\hline ב & $\begin{array}{l}\text { Outcomes: first major vascular events (ie, non-fatal myocardial } \\
\text { infarction or coronary death, stroke, or revascularisation } \\
\text { procedure). Secondary outcomes included total (non-fatal and } \\
\text { fatal) stroke, presumed ischaemic stroke, and haemorrhagic } \\
\text { stroke. }\end{array}$ \\
\hline$\vec{\square}$ & $\begin{array}{l}\text { Patient follow up: }\{99.7 \% \text { of patients had complete follow up } \\
\text { over } 5 \text { years\}† (intention to treat analysis). }\end{array}$ \\
\hline & $\begin{array}{l}\text { *See glossary. } \\
\text { †Heart Protection Study Collaborative Group. Lancet } \\
2002 ; 360: 7-22 \text {. }\end{array}$ \\
\hline
\end{tabular}

\section{MAIN RESULTS}

At 5 years, patients in the simvastatin group had greater reductions in first occurrence of major vascular events and stroke than patients in the placebo group (table). The groups did not differ for haemorrhagic stroke $(0.5 \% \vee 0.5 \%)$.

For correspondence: Heart Protection Study, Radcliffe Infirmary, Oxford, UK. hps@ctsu.ox.ac.uk

Sources of funding: UK Medical Research Council; British Heart Foundation; Merck \& Co; Roche Vitamins Ltd.

\section{CONCLUSION}

Cholesterol lowering with simvastatin reduced stroke in patients with, or at high risk of, vascular disease.

Abstract and commentary also appear in ACP Journal Club.

\section{Commentary}

The primary results of the impressive Heart Protection Study were published in 2002 and showed that simvastatin reduced the risk of major vascular events in patients at high risk. ${ }^{\prime}$ In the current subgroup analysis, more complete data are provided on the effect of therapy on risk of stroke in the overall cohort and on major vascular events in the subgroup with cerebrovascular disease at study entry. Subgroup analyses have rightly earned a bad reputation for producing findings of questionable significance; however, this analysis confirms the findings of the overall study and is less susceptible to bias. The investigators are asking the question, do results really apply to the specific diseases that were clustered together in the primary analysis?

Other recent trials have also shown benefits of statins in reduction of stroke and cardiovascular events, independent of baseline cholesterol concentrations and with various other statins. ${ }^{2}$ Although this trial did not include patients with vascular events occurring within 6 months before randomisation, statin initiation during hospitalisation for ischaemic stroke or transient ischaemic attack of atherosclerotic origin is probably justified and may increase rates of long term use. Results of the ongoing Stroke Prevention by Aggressive Reduction in Cholesterol Levels (SPARCL) trial ${ }^{3}$ may provide confirmation of the role of statins in the minority of patients with previous stroke but no history of cardiovascular disease, other occlusive arterial disease, or diabetes. In the meantime, we will be initiating statins in all patients who can tolerate them after atherothrombotic stroke or transient ischaemic attack.

S Claiborne Johnston, MD, PhD University of California, San Francisco San Francisco, California, USA

1 Heart Protection Study Collaborative Group. MRC/BHF Heart Protection Study of cholesterol lowering with simvastatin in 20,536 high-risk individuals: a randomised placebo-controlled trial. Lancet 2002;360:7-22.

2 Corvol JC, Bouzamondo A, Sirol M, et al. Differential effects of lipidlowering therapies on stroke prevention: a meta-analysis of randomized trials. Arch Intern Med 2003;163:669-76.

3 Sillesen H, Callahan AS. Design of the Stroke Prevention by Aggressive Reduction in Cholesterol Levels (SPARCL) Study. The American Stroke Association $28^{\text {th }}$ International Stroke Conference. February 13-15, 2003. http://216.185.112.6/sc_includes/pdfs/CTP21.pdf

Simvastatin $(\mathrm{Sim}) v$ placebo in patients at high risk of vascular disease*

\begin{tabular}{lllll}
\hline $\begin{array}{l}\text { Outcomes } \\
\text { at } 5 \text { years }\end{array}$ & Sim & Placebo & RRR (95\% Cl) & NNT (CI) \\
\hline$\geqslant 1$ major & $20 \%$ & $25 \%$ & $24 \%(19$ to 28$)$ & $17(15$ to 21$)$ \\
$\begin{array}{l}\text { vascular event† } \\
\geqslant 1 \text { stroke }\end{array}$ & $4.3 \%$ & $5.7 \%$ & $25 \%(15$ to 34$)$ & $71(52$ to 117$)$ \\
$\geqslant 1$ ischaemic stroke & $2.8 \%$ & $4.0 \%$ & $30 \%(19$ to 40$)$ & $84(63$ to 133$)$ \\
\hline
\end{tabular}

*Abbreviations defined in glossary; NNT and Cl calculated from control event rate and rate ratio in article.

†Non-fatal myocardial infarction or coronary death, stroke, or revascularisation procedure. 